\title{
Utilization of Milkfish for Milkfish Dumplings for The Community of Serang
}

Dabella Yunia ${ }^{1}$, Muhammad Galih Ferginanto²

1,2,3,4,5 University of Sultan Ageng Tirtayasa, Indonesia

galihferginanto@gmail.com² ${ }^{2^{*}}$

Abstrak

Pengabdian kepada masyarakat ini bertujuan untuk meningkatkan kreativitas masyarakat yang memberikan nilai tambah ekonomi bagi bandeng. Kegiatan ini dilakukan dengan mengajak masyarakat untuk memberikan presentasi kewirausahaan, kemudian memberikan pelatihan membuat pangsit bandeng. Ini adalah strategi bisnis yang sekaligus mengangkat sumber daya lokal.

Kata kunci: Bandeng, Pangsit Bandeng, Nilai Tambah Ekonomi.

Abstract

This community aims to increase the creativity of the community which provides value added economic for milkfish. This activity was carried out by inviting the community to give presentations on entrepreneurship, then providing training to make milkfish dumplings. This is a business strategy that simultaneously raises local resources.

Keywords : Milkfish, Milkfish Dumplings, Economic Value Added.

\section{Introduction}

Sawah Luhur Village, Kasemen District is one of the districts in Serang City. Its position is close to the center of Serang city government. However, in this area there is a lot of untapped potential, namely the community's potential to be independent. Most of the female population in the Kasemen area do not work, they are housewives every day. From a physical and health perspective, women in the Kasemen area have the potential to be economically independent. This is supported by the strategic location of Serang city.

Serang City is the capital city of Banten province. This predicate as the capital of the province makes Serang visited by many parties from various regions, both Banten and outside Banten. This visit was carried out in connection with the predicate of Serang City as an administrative city in Banten and even Serang City is also known as a religious tourism city. The city of religious tourism is increasingly visited after the revitalization of the Old Banten.

Besides being famous for religious tourism, Serang City is known as a city that has a variety of processed milkfish. Naturally, every traveler to Serang brings milkfish as souvenirs. This is none other than because it is easy to obtain milkfish raw materials in Serang City. Based on data from the Central Statistics Agency in 2013 fish resources came from Serang City as much as 809.74 tons, and this number is the highest number among other Serang areas.

Many people in Serang have processed milkfish into processed foods that are unique and have a high taste. The processed foods are in the form of milkfish satay, 
grilled milkfish, and fried milkfish. Of the various kinds of typical Serang souvenirs made from milkfish, there are no dumplings made from milkfish. This is an opportunity for the community to create milkfish dumplings. Based on data from the Central Statistics Agency (BPS, 2008) cited in the Indonesian megapolitan noodle and meatball trader association (Indonesian Miso Association), in 2006 of the 48.7 million SMEs in Indonesia, 20 percent or about 10 million of them were meatball noodle business traders. It can be interpreted that the majority of SMEs are meatball traders. The number of meatball traders is certainly a result of the large demand for meatballs from consumers (Sembiring, 2010).

The basic ingredients of milkfish, apart from having a variety to be processed, it turns out that milkfish contains vitamins that are beneficial for the body. Based on Halifudin's research (2015) Milkfish is a fish that is rich in protein sources (20-24\%), fats, amino acids, fatty acids, minerals and vitamins with a meat yield of about $12 \%$ (fresh water) and $50.8 \%$ (brackish water). . The highest amino acid composition is gulatamate, while the highest unsaturated fatty acid is oleic 31-32\%, macro minerals in milkfish meat are: $\mathrm{Ca}, \mathrm{Mg}, \mathrm{Na}$ and $\mathrm{K}$. While the micro minerals are $\mathrm{Fe}, \mathrm{Zn}, \mathrm{Cu}, \mathrm{Mn}$. The vitamin content of milkfish meat includes vitamins A, B1 and B12. This allows milkfish to be processed into a healthy meal.

The predicate of Serang city as a religious tourism city and abundant fish resources are the basis for creating milkfish dumpling products. The people of Serang and its surroundings are easy to find resources, namely milkfish. In addition, Serang city's position as a city for religious tourism supports potential markets, so that milkfish dumpling products are easier to find and market both by travelers and fans of wonton noodles. With the described background, the researcher intends to develop the potential of human resources in Kasemen District by using natural resources and expertise to process innovative milkfish dumplings to become a food icon for the city of Serang, Banten. The formulation of the problem for community service is how to use milkfish to support an independent economy for the residents of Kasemen, Serang.

\section{Implementation Method}

The method is an important technique so that the above plan can be realized. The steps for making milkfish dumplings include:

\section{Planning}

Planning begins with a group discussion with the supervisor. Then after reaching an agreement, the PKM-M group made an agreement with the target partners. Third, the program that has been prepared will be socialized to the people in Sawah Luhur, Kasemen, Serang, Banten.

2. Organizing

The division of tasks includes the responsibilities of each existing member and the distribution of tools and materials that need to be properly prepared. The tools and materials used include tools that support the activities of this program. These tools and materials will be used to hold discussions with related parties, make milkfish dumplings, and make proposals and documentation related to community service.

3. Implementation of Activities

The training activity for making milkfish dumplings was carried out for 1 full day. Where, the tools and materials have been prepared the day before the activity is carried 
out. The implementation was carried out in one of the residents' houses in the Sawah Luhur Village, Kasemen District, Serang City, Banten.

\section{Control}

Control of activities is carried out to ensure that activities are carried out properly and the community can accept the knowledge conveyed, and be able to apply it in real life.

\section{Result and Discussion}

Sawah Luhur is a village in Kasemen sub-district, Serang City, Banten, Indonesia. This village is the granary of rice throughout the city, although its public life is inversely proportional to this title. Its area is 1,800 hectares (ha), consisting of 900 ha of rice fields, 515 ha of fish/shrimp ponds, and the rest consists of vacant land and public settlements.

Based on data on the potential of Sawah Luhur Village, the main sources of livelihood for the residents of Sawah Luhur Village are farmers and fishermen. Sometimes people also have multiple livelihoods. This is caused by the factor of job opportunities, if there is an opportunity to work on a building project there are those who are able to become builders and workers. If they are not available, they turn to livestock business and also depend on the current season regarding the problem, here are the types of livelihoods for the people of Sawah Luhur Village:

Table 1. Livelihoods of the residents of Sawah Luhur Village

\begin{tabular}{llll}
\hline No & \multicolumn{1}{c}{ Type of work } & $\begin{array}{c}\text { Number } \\
\text { (Soul) }\end{array}$ & \multicolumn{1}{c}{$\begin{array}{c}\text { Business } \\
\text { Code }\end{array}$} \\
\hline $\mathbf{1}$ & Farmers/Growers & 863 people & Active \\
$\mathbf{2}$ & Fisherman/ Fishery & 22 people & Active \\
$\mathbf{3}$ & Private sector employee & 146 people & Active \\
$\mathbf{4}$ & Government employees & 32 people & Active \\
$\mathbf{5}$ & Freelance & 968 people & Active \\
$\mathbf{6}$ & Trader & 16 people & Active \\
$\mathbf{7}$ & Driver & 10 people & Active \\
$\mathbf{8}$ & Plantation Farm Workers & 65 people & Active \\
$\mathbf{9}$ & Taking care of household & 2453 people & Active \\
$\mathbf{1 0}$ & Student/ Student & 1265 people & Active \\
$\mathbf{1 1}$ & entrepreneur & 742 people & Active \\
$\mathbf{1 2}$ & Retired & 10 people & Active \\
$\mathbf{1 3}$ & Teacher & 11 people & Active \\
$\mathbf{1 4}$ & Honorary Employee & 18 people & Active \\
$\mathbf{1 5}$ & Other Services & 398 people & Active \\
\hline
\end{tabular}

Source: data has been documented in Sawah Luhur village, 2017 
Judging from the table above, it can be concluded that the majority of the livelihoods of Sawah Luhur Village are as laborers and farmers. However, the author is more interested in conducting research on people who work as fishermen, this isbecause the number of fishermen is not too much, and the distance of the community is also not far from the author's house, so that it can make it easier for the author to collect data and sources of information. As the father of the welfare of the Sawah Luhur village said: Since the Sawah Luhur village is close to the sea, the people here work as fishermen, other than that there are fish traders. The fisherman's wife usually sells her husband's fish catch to the market. He further explained that most of the livelihoods of the people of Sawah Luhur sub-district are double, meaning that at certain times those who are farmers can also become fishermen, and vice versa.

The entrepreneurship briefing activity was held on August 10, 2020. This activity was carried out with the aim of opening public interest in entrepreneurship so that they could help the family economy. The first material presented was about the definition of entrepreneurship. Entrepreneurship is an attempt to create value through business opportunities. Businesses carried out by entrepreneurial people do not need to be difficult, they must look for businesses that are easy to do. This business can also start as a hobby. So, don't look at a hobby as just a pleasure, but it can also generate rupiah. In addition, businesses with local resources. This can be done in order to raise the good name of the region.

If Banten is famous for its milkfish, then people can make a business based on milkfish. Such as milkfish satay, milkfish pecak, fried milkfish, grilled milkfish, and others made from milkfish (Yunia dkk, 2020). The community can also make food innovations in terms of making milkfish dumplings. This is a delicious, nutritious food innovation that can raise the good name of Banten.

The training activity to make milkfish dumplings is a follow-up activity from the entrepreneurship briefing activity. This training activity consists of two sessions, the first session is a session where making meatballs, while the second session is product packaging. The result of this activity is milkfish dumplings in attractive packaging. The preparation carried out is to prepare the tools and materials that will be used to make milkfish dumplings. The process of making milkfish dumplings is quite easy. Training participants can follow the steps guided by the resource person.

The milkfish dumplings were successfully made by residents of Kasemen, Serang City, Banten. This shows that milkfish have the potential for added value to become entrepreneurs. This is shown by the residents being able to convert milkfish into other goods that can be sold at a higher price. The results of this study support the research conducted by Martati, Indah., et al, 2013 that the home industry business sector has the potential to process local resources so as to improve the regional economy (Martati, Indah., et al, 2013).

\section{Conclusion}

The residents of Kasemen, Serang Banten have understood the concept of entrepreneurship. Entrepreneurship that is raised here is a local resource that has the potential to improve community welfare, namely milkfish. Milkfish is processed into 
milkfish dumplings. Milkfish dumplings can provide added value and wider distribution. With the provision of entrepreneurial knowledge and skills, it is hoped that it can add to the community's economy.

\section{Acknowledgment}

Thank you to the parties who have participated in supporting this activity, namely the people of Kasemen, Serang and the Faculty of Economics and Business, University of Sultan Ageng Tirtayasa.

\section{References}

Badan Pusat Statistik. 2008. Katalog BPS. Bogor: Badan Pusat Statistik Kota Bogor.

Halifudin. 2015. Analisis Kandungan Gizi Pada Ikan Bandeng yang Berasal dari Habitat yang Berbeda. Jurnal kelautan, vol 8, no 1, April 2015, issn:1907-9931.

Martati, Indah., Suminto \& Syarifuddin, Andi. 2013. Model of Job Creation Through Local Economic Development in Samarinda llir District. Journal of Management and Entrepreneurship. Vol.15 (No.2), 123-130. two:https://doi.org/10.9744/jmk.15.2.123-130.

Sembiring. Monalisa. 2010. Analisis Pendapatan Pedagang Bakso Di Kota Bogor Jawa Barat.[skripsi]. Bogor:Fakultas Ekonomi dan Manajemen, Institut Pertanian Bogor.

Sukirno, Sadono. 2013. Mikroekonomi Teori Pengantar. Jakarta: Rajawali Pers

Yunia, D., Prasadhita, C., \& Salam, D. M. (2020). Pemberdayaan Masyarakat Membuat Bakso Bandeng di Kelurahan Unyur, Serang, Banten. KAIBON ABHINAYA: JURNAL PENGABDIAN MASYARAKAT, 2(2), 61-65. 